\title{
EUTHANASIA: A MUSLIM'S PERSPECTIVE
}

\author{
Mahmud Adesina Ayuba \\ Department of Religion \& African Culture \\ Adekunle Ajasin University \\ Nigeria
}

\begin{abstract}
Availability of advanced medical technology has generated various new moral issues such as abortion, cloning and euthanasia. The use of medical technology, therefore, raises questions about the moral appropriateness of sustaining life versus taking life or allowing someone to die. Moreover, the world-wide discussion on euthanasia has assumed different dimensions of acceptance and rejection. The modern advanced medical technology has brought this issue under extensive focus of philosophers and religious authorities. The objective of this article is to consider the Islamic ethical position on euthanasia with a view to appreciating its com-prehensiveness and investigating how an Islamic approach to medical treatment addresses the issue. The study observes that Allah gives life and has the absolute authority of taking it. In other words, the Qur'an prohibits consenting to one's own destruction which could be related to terminally ill patients who give consent to mercy killing. The study equally revealed that death is not the final destination of human beings but the hereafter; therefore, a believer should not lose hope when facing difficulties, suffering and hardship but should instead keep hope alive. The study calls on Muslims to ensure that Islamic teachings on medical ethics are entrenched in all fabrics of human endeavour.
\end{abstract}

Key Words: Islam; Euthanasia; Ethics; Medicine; Qur'an; Sunnah

\section{Introduction}

Euthanasia is a contemporary issue in the jurisprudence of right. Many people such as Fletcher and Brockopp ${ }^{1}$ are in support of it, while some people like Banner and alQaradawi $^{2}$ have argued against it. ${ }^{1}$ The argument of the supporters of euthanasia, as we are going to see as we progress, is that to leave somebody in the state of pain could be tantamount to allowing him/her to suffer the more. They argue that the best thing to do is to help him/her terminate his/her life. Religiously and more importantly, Islamic law and some moralists are vehemently opposed to this position. To them, God is the Creator of lives and reserves the right to take them at the right time. They argued that, no matter the precarious condition of a creature of God, there is still hope for survival.

An investigation into euthanasia reveals that the practice involves three parties, namely the dying patient, the family of the dying patient and the doctor who is to perform the action. The dying patient may use his/her initiative to request a doctor to terminate her/his life voluntarily out of distress. This type of euthanasia is known as 'voluntary euthanasia'.3 It is involuntary when it is performed without the consent of the patient but with the knowledge of the relatives of the patient who are worried by his pain and distress. ${ }^{4}$ The doctor, on the other hand, has the option of either terminating the life of a dying patient by 
recommending an overdose of painkillers, or withdrawal of certain treatment, or by switching off the life support machine with the aim of terminating the patient's life. Technically, the former is called 'active euthanasia' while the latter is known as 'passive euthanasia'.

Moreover, the debate on end-of-life issues became pertinent in the late 20th. Although there is unavoidable overlap between suicide and euthanasia, the debate on them became separated along with their subject matter and arguments. As a result, the nature of euthanasia is more pertinent to the medical profession and the debate over rights of patients and duties of clinicians. Thus broadly, euthanasia becomes interdisciplinary as the issue is being discussed by philosophers, physicians, religious bodies, academics and human rights activists, among others.

For instance, it was legalised under certain circumstances in the Netherlands in 2002, while it is considered illegal in the United Kingdom. The Northern Territory of Australia's law which permitted euthanasia came into effect in June of 1996, only to be overturned in March of $1997 .{ }^{6}$ Switzerland and the American State of Oregon allow only physicianassisted suicide. ${ }^{7}$ Many countries are also trying to strike a balance between ethical and practical laws governing it. ${ }^{8}$ This is an indication that divergence of opinions characterize the legality, or otherwise, of the practice of euthanasia.

In addressing the issue of euthanasia from a Muslim point of view, responses have come from various sections such as organisations of Muslim doctors, independent writers, and above all from the Islamic jurisprudential bodies and Islamic medical code. ${ }^{9}$ The aim of this article, therefore, is to examine the position of Islam regarding euthanasia with a view to appreciating its rules on the sacredness of life, among other things.

In the course of doing justice to the topic, the article aims to examine the meaning of euthanasia and its types - active and passive - before moving to the relationship between homicide, suicide and euthanasia. A Muslim approach to life, death and dying will also be analysed under active euthanasia. The article then examines medical treatment from an Islamic perspective before finally looking at some issues under passive euthanasia. Let us now examine the meaning of euthanasia.

\section{Euthanasia: What is it?}

Etymologically, euthanasia comes from two Greek words, eu, meaning 'well', and thanatos, meaning 'death', so it means a good or easy death. In the course of time, the meaning of the term gained the connotation of 'mercy killing' ${ }^{10}$ The common synonym for euthanasia, therefore, in the lay and professional vocabularies has been mercy killing. In Arabic works on euthanasia, the term has been rendered as qatalur-rahmah, meaning (literally) 'mercy killing'. Merriam-Webster's dictionary defines euthanasia as 'an easy and painless death, or, an act or method of causing death painlessly so as to end suffering: advocated by some as a way to deal with victims of incurable disease'. ${ }^{11}$

The Oxford Advanced Learner's Dictionary also defines euthanasia as 'the practice of killing without pain of a person who is suffering from an incurable and painful disease'. ${ }^{12}$ The Euthanasia Society of America that was founded in 1938 defines euthanasia as the 'termination of human life by painless means for the purpose of ending severe physical suffering'. ${ }^{13}$ And the American Medical Association's Council on Ethical and Judicial Affairs defines it as 'the act of bringing about the death of a hopelessly ill and suffering person in a relatively quick and painless way for reasons of mercy'. ${ }^{14}$ Motlani, however, 
argues that the term 'euthanasia' has no generally accepted and philosophically warranted core of meaning. ${ }^{15}$

Moreover, there are two different uses of the term 'euthanasia'. The first is sometimes called the narrow construal of euthanasia, by which euthanasia is equivalent to mercy killing. Hence, when a physician injects a patient with a drug with the intent to kill him, it would be an act of euthanasia; but if a physician withholds some extraordinary and excessively burdensome treatment from a patient and allows him to die in a natural way, it does not come under euthanasia. The second one is called the broad construal of euthanasia. This comes under the definition of euthanasia as mercy killing and cessation of extraordinary medical treatment; that is, active and passive euthanasia. ${ }^{16}$

Active euthanasia or euthanasia by action, which is also called positive euthanasia, means 'intentionally causing a person's death by performing an action such as giving a lethal injection'. Passive euthanasia or euthanasia by omission, which is also called negative euthanasia is "withholding or withdrawing the necessary and extraordinary medical treatment'. ${ }^{17}$ The Arabic term for active euthanasia is qatalur-rahmah al-ijābi , while passive one is called qatalur-rahmah al-salibi .

The clash of views at the conceptual level of defining the terms from the Western bioethical perspective has made much of the debate, as a result frustrating clarity on the use of the term 'euthanasia' in a diverse sense. However, Muslim scholars in the field have responded to these modern bioethical issues in a systematic way through fatwa literature (jurisprudential decrees) like that of Shaykh Muzammil, medical codes and jurisprudential conferences. ${ }^{18}$ In a nutshell, Islamic writings carried out an in-depth research into euthanasia by using the same categories as set by the Western bioethics when bioethics started long ago as a discipline in the Western countries, especially in the United States. ${ }^{19}$

\section{The Relationship between Homicide, Suicide and Euthanasia}

The historical account of the debate regarding end-of-life issues has remained focused on the subject of suicide; and euthanasia has been considered part of it. Indeed, seeking a clear separation between them which was necessitated by legal and ethical implications is a recent development. The ethical and legal implications of euthanasia are more far-reaching than those surrounding suicide. ${ }^{20}$ The difference between suicide and euthanasia are present in Islamic jurisprudential works of Imams Abu Hanīfah, Shāfi‘'i and Hanbali, where essential distinctions are drawn between suicide (intihār), assisted suicide and homicide $\left(\right.$ qatl). ${ }^{21}$

The delineations between them are made mainly to recommend different penalties for different cases. From the Islamic perspective, the difference between euthanasia and suicide could be seen from legal and ethical grounds. The reason is that it is prohibited for a person to commit self-killing (suicide), whereas in euthanasia, it would be prohibited for both the one who seeks self-killing as well as the one who assists such a person in committing suicide. ${ }^{22}$ On the other hand, there are factors which made suicide and euthanasia similar, such as wishing for death and ending a life. Euthanasia, according to Motlani may be distinguished from suicide as a person wishing to commit suicide may not need any support or knowledge of another to terminate his life. ${ }^{23}$ The sanctity of life remains central in the arguments and debates on suicide and euthanasia.

Moreover, Jurists like Imam Abu Hanīfah, Shāfi ‘⿳亠 and Hanbali classify homicide into intentional, quasi-intentional and inadvertent homicide. ${ }^{24}$ Intentional homicide occurs when 
a person intentionally uses an object that could kill against another person whose blood is sacred and which consequently leads to the death of that person. ${ }^{25}$ Quasi-intentional homicide occurs when a person injures another man without having the intention of taking his life but due to the injury sustained, the victim eventually dies. ${ }^{26}$ A homicide becomes inadvertent when an offender intends a target other than a human being but he mistakenly hits a human being, causing his death. ${ }^{27}$

The classification above reveals that intentional homicide has a close connection with euthanasia, as it is intentionally carried out by the doctor on a person whose life is protected by law for a reason known to him. Quasi-intentional and inadvertent homicide could be classified under professional negligence on the part of the medical doctor.

Some leading Muslim Jurists have likened euthanasia to murder and therefore concluded that the practice is haram (forbidden). For instance, Al-Qaradawi ${ }^{28}$ issued a fatwa (jurisprudential decree or legal opinion) equating euthanasia to murder. The Late Grand Mufti of Saudi Arabia, Abdul-Aziz bin Abdullah bin Baz equally declared it un-Islamic for anybody to decide the death of a person before he is actually dead. ${ }^{29}$ Equating euthanasia to suicide, the Islamic Code of Medical Ethics issued by the First International Conference on Islamic Medicine states. ${ }^{30}$

Mercy killing like suicide finds no support except in the atheistic way of thinking that believes that our life on this earth is followed by void. The claim of killing for painful hopeless illness is also refuted, for there is no human pain that cannot be largely conquered by medication or by suitable neurosurgery...

The next segment discusses two types of euthanasia; the active and passive types for the purpose of clarity.

\section{Active Euthanasia}

Active euthanasia is a 'narrow construal' of euthanasia. ${ }^{31}$ This is real euthanasia because it refers to intentional death of a terminally ill patient by action. Technically, active euthanasia excludes suicide, assisted suicide and physician assisted suicide. Suicide is selfkilling while assisted suicide occurs when someone provides an individual with information, guidance and means to take his or her own life with the intention that it will be used for this purpose. Likewise, when it is a doctor who helps another person to kill the patient it is called physician-assisted suicide. Therefore, the definition of active euthanasia is: A physician's act that causes a terminally ill person's death intentionally for the reason of mercy.

To be precise, active euthanasia is voluntary as per its use in the current debate on the issue. However, there are three types of active euthanasia and the difference between them is mainly based on the nature of the patient's consent. According to al-Qaradawi, the three types of euthanasia are voluntary, involuntary and non-voluntary euthanasia:

Voluntary euthanasia occurs whenever a competent, informed patient autonomously requests it. Non-voluntary euthanasia occurs whenever a person is incapable of forming a judgment or expressing a wish in the matter (e.g. a defective newborn or a comatose adult). Involuntary euthanasia occurs when the person expresses a wish to live but is nevertheless killed or allowed to die. ${ }^{32}$

In Islamic literature and works on bioethics, definitions which clearly try to make definitional content clearer are those given in the International Islamic Code for Medical 
and Health Ethics. The code defines mercy killing and what it includes in article 61 as follows:

A physician should not take part in terminating the life of a patient... This particularly applies to the following cases of what is known as mercy killing:

(a) the deliberate killing of a person who voluntarily asks for his life to be ended,

(b) physician-assisted suicide, and

(c) the deliberate killing of newly born infants with deformities that may or may not threaten their lives. ${ }^{33}$

From the study of the above code, it appears that a physician would be said to have committed an immoral and illegal act if he involves himself in killing a patient whether directly or indirectly. The aforementioned definition in the code - also a physician-oriented definition - gives an ethical guideline to a physician. However, it does not locate the position of the patient and his ethical position on the issue. This presents a broader definition of mercy killing, which includes voluntary euthanasia, non-voluntary euthanasia, involuntary euthanasia and physician-assisted suicide. The definition is based on the prohibition of killing and the cases are not just a matter of ethical discussion, but they also have legal implications. According to Motlani, some scholars such as Warnock and Macdonald $^{34}$ observe that voluntary active euthanasia also known as 'aid-in-dying' must, in most cases, involve the patient's consent to euthanasia: this may appear in a verbal expressed statement or writing. However, they argue that the word 'voluntary' should be substituted with 'begging to die', 'asked for', 'requested' or 'chosen' ${ }^{35}$

Summarily, mercy killing is ethically wrong and it comes under the broader guidelines of the Qurán and Sunnah which are against killing innocent beings and against participating or collaborating in committing sin (ithm). The Qurán, chapter 5 verse 2 states: “...And do not help each other in sin (ithm) and aggression...".36 Therefore, the debate on what constitutes active euthanasia remains irrelevant to seeking Islamic ethical guideline on how a physician should perform his responsibilities while dealing with terminally ill patients. That includes every act on the part of the physician which involves any assistance or guidance in killing terminally ill patients and is ethically prohibited in Islam.

According to Muslim scholarship, the following forms of euthanasia are prohibited: voluntary euthanasia, involuntary euthanasia, non-voluntary euthanasia and physicianassisted suicide. That being the case, it must be stated that the position of Islam as regards the conception of life and its sanctity makes killing or mercy killing prohibited.

In the next section, we will talk briefly on the Islamic approach to life and its sanctity.

\section{Islam's Approach to Life, Dying and Death}

A Muslim scholar, Ebrahim, ${ }^{37}$ posits that like other religions, Islam upholds the sanctity of life and quotes the Qur'an, chapter 5:28 to support his position as follows:

If you do stretch your hand to slay me, it is not for me to stretch my hand to slay you for

I do fear God the Cherisher of the worlds.

Islam, however, teaches that human beings are God's vicegerent (Al-khalifah) in this world (Qur'an 2:30-31) and God (Allah - hereafter this term will be used throughout the text instead of the term 'God' $)^{38}$ has given human beings respect by giving them control and power over many things (Qur'an 22:65). Muslims are expected to have faith (imān) and 
with their faith, they are advised to have virtues of patience and endurance (sabr) to be able to face the challenges of life. Qur'an 2:155-157 confirms thus:

But give glad tidings to those who patiently persevere. Those who say when affected with calamity, 'To Allah we belong and to Him is our return'. They are those on whom descend blessings from their Lord and mercy. They are the ones who receive guidance.

In addition, Islam according to Malik, ${ }^{39}$ provides a cohesive social system and set of rules which keeps a community of believers in warm relationship with each other. In other words, it provides an atmosphere in which individuals are morally, emotionally and physically supported. In taking care of ill people, Islam provides a support system in the form of family in which duties of maintenance, compassion and kindness are to be maintained. If these notions were properly understood, a Muslim would never contemplate committing suicide. ${ }^{40}$ Even, for, According to the Qur'an, a Muslim's life constitutes a trial and a test for the human, by means of which his final destiny is determined (by God). For him, death is the return of the soul to its Creator, God. In another words, death marks the transition from one state of existence to the next. The Qur'an says:

Be sure that We shall test you with something of fear and hunger, some loss in goods or lives or the fruits of your toil, but give glad tidings to those who patiently persevere (AlQur'an 2:155).

You shall certainly be tried and tested in your wealth and properties and in your personal selves... (Al-Qur'an 3:186).

Islam teaches that Allah gives life and has the absolute authority of taking it. Allah has apportioned a terminal period to each soul to which upon its expiration, a second cannot be added by anybody. In short, Allah alone has control over death (Qur'an 16:61). The maintenance of the sanctity of life is further enhanced when Allah instructs: "Do not take life which Allah made sacred, other than in the cause of justice" (Qur'an 17:33). "The enormity of the sin on a person who deliberately terminates a life other than in the course of justice such as murder or spreading mischief in the land, is as if the whole people have been killed by him" (Qur'an 5:32). ${ }^{41}$ This means that Islamic law prescribes the death penalty for those who commit grave crimes in order to ensure peace, security and tranquility in the society. Based on the following Qur'anic chapter: "O you who believe! Al-Qisas (just retribution) is ordained for you in respect of the murdered (Qur'an 2:178)"; Ebrahim observes that God uses the word al-qisas (just retribution) to ensure that only the guilty of the crime will lose his life when the death sentence is to be carried out. ${ }^{42}$

With the above Qur'anic verses, it is clear that someone who terminates the life of another person is only unfortunate, as the person killed has been predestined ${ }^{43}$ to die at that particular time because no person can die except by Allah's leave at an appointed time. The Qur'an says: “And no human being can die save by Allah's leave, at a term preordained (Qur'an 3:145)". The verses explicitly prohibit suicide, euthanasia (killing by clinicians) and other types of homicide. Moreover, the Qur'an also prohibits someone causing own destruction which is an indication that active euthanasia is, indeed, wrong and prohibited. In other words, it gives a clear position regarding the main facts related to euthanasia: all of, which includes prohibition of killing, prohibition of helping on prohibited acts, consenting to self-destruction and suicide. The Qur'anic chapter 2:195 attests to this: "And spend in the cause of Allah and do not throw yourselves into destruction and do good. Truly, Allah loves the good-doers". 
The tradition of Prophet Muhammad also prohibits killing of innocent soul. He was reported to have said: "The biggest of the great sins (al-kabā'ir) are to join others as partners in worship with Allah, to murder a human being, to be undutiful to one's parents and to make a false statement or give a false witness". ${ }^{44}$ A companion of the Prophet, Abdrahman Bin Sahr (popularly known as Abu Hurayrah) also narrated that the Prophet said: He who commits suicide by throttling shall keep on throttling himself in the Hell Fire (forever) and he who commits suicide by stabbing himself shall keep on stabbing himself in the Hell Fire. ${ }^{45}$

In a similar way, Muslim scholars have unanimously prohibited active euthanasia and physician-assisted suicide because both are prohibited by the injunctions of the Qur'an and Sunnah. According to Yusuf Al-Qaradawi, "this is an act of killing and killing is a major sin and thus forbidden in Islam, the religion of pure mercy" ${ }^{46}$ We now discuss passive euthanasia.

\section{Passive Euthanasia}

Passive euthanasia is also known as euthanasia by omission or as negative euthanasia; this happens when one withholds or withdraws the necessary and extraordinary medical treatment from a terminally ill patient, thus allowing the patient to die. ${ }^{47}$ There are some scholars who do not treat passive euthanasia as euthanasia. Outright rejection or permission of passive euthanasia would not be appropriate without making it clear what it is and how different cases under it could be categorised.

Some forms of passive euthanasia are: ${ }^{48}$

- Withdrawing medical treatment from terminally ill patients.

- Withholding medical treatment from terminally ill patients.

- Pain medication that may hasten death of a terminally ill patient as a side effect.

- Discontinuing life support systems such as ventilators.

- Refusing medical treatment to terminally ill patients.

- Do Not Resuscitate (DNR).

Passive euthanasia, as explained above, does not mean one single method but a variety of options a physician and patient face. Since it is unanimously held that passive euthanasia is not about failing to implement medical treatment for patients to recover, but for those patients who die due to underlying diseases, the question arises: when and in what circumstances is it permissible to withhold, withdraw, refuse and induce pain medication that will suppress the pain and hasten the death?

Moreover, is it permissible to let a patient starve to death by discontinuing the feeding tube and hydration? When is it permissible for a patient to refuse medical treatment? Is DNR permissible? Solutions to these issues are possible only when a well-conceived understanding of the Islamic approach to medication is understood. The next segment concentrates on the Islamic stance on medical treatment.

\section{Medical Treatment: A Muslim's Viewpoint}

Islamic guidance on medical treatment is based on the basic sources of Islam; that is the Qur'an and Sunnah. Moreover, maxims of Islamic jurisprudence (al-qawā'id al-fiqhiyyah) which are drawn on these sources have wider applicability on the issues which come under passive euthanasia. 
The Qur'an clearly provides injunctions and commandments which prohibit killing; whereas Sunnah - as a collection of traditions of Prophet Muhammad - is fairly comprehensive in providing an Islamic approach to medication. The Sunnah includes various traditions which are helpful in formulating an Islamic approach to medication in general and to discourage medicinal treatment in a particular way. Among these traditions are those which encourage medical treatment such as Imam Ahmad who, in his book of Hahith, Musnad, narrated that Usāmah bin Shurayk (a companion of the Prophet) said:

I was with Prophet Muhammad when the Bedouins came to him and said, 'O' Messenger of Allah, should we seek medicine? He said, 'Yes O' servants of Allah seek medicine, for Allah has not created a disease except that He has created its cure, except for one illness'. They said, 'And what is that?' He said, 'Old age. ${ }^{, 49}$

It is also narrated that a companion, ${ }^{50}$ Abu Khuzāmah said: I said, 'O Messenger of Allah, the Ruqyah (divine remedies - Islamic supplication formula) that we use, the medicine we take and the prevention we seek, does all this change Allah's appointed destiny? He said, "They are in fact a part of Allah's appointed destiny". 51 Abu Hurayrah also narrates: The Prophet said: "There is no disease that Allah has created, except that He has also created its treatment". 52 Ebrahim, however, notes that Muslims generally view affliction with a disease as a test of their faith and that such tribulation contributes to expiation of their sins ${ }^{53} \mathrm{He}$ then quotes a prophetic tradition which stated that: When a Muslim is tried with a disease in his body, it is said to the angel: "Write for him the good actions which he used to do. If He (Allah) cures him, He (Allah) absolves him (of all sins); and if He (Allah) takes his life (as a result of this disease), He (Allah) forgives him and shows mercy upon him". 54

On the other hand, there are traditions which allow refusal of medication; this according to narration of Prophet Muhammad's wife, 'Aishah ${ }^{55}$ (an indication that Islam encourages medication). She relates an incident that took place before Prophet Muhammad's demise. She states: "We put medicine in one side of his mouth, but he started waving to us not to insert the medicine into his mouth. We said: He dislikes the medicine as a patient usually does. But when he came to his senses, he said: Did I not forbid you to put medicine (by force) in the side of my mouth..."

Moreover, some scholars argue over which is better for the patient: treatment or showing endurance (sabr). Those who maintain that showing endurance is far better, base their judgment on the narration of Ibn 'Abbās, Ata' ibn Ab̄i Rabīh (a companion of the Prophet), said Ibn 'Abbās to me:

May I show you a woman of Paradise? I said: Yes. He said: Here is this dark-complexioned woman. She came to Allah's Apostle and said: I am suffering from falling sickness and I become naked; supplicate Allah for me. Whereupon he (the Prophet) said: Show endurance $(s a b r)$ as you can do and there would be Paradise for you and if you desire, I supplicate Allah that He may cure you. She said: I am prepared to show endurance (but the unbearable trouble is) that I become naked, so supplicate Allah that He should not let me become naked, so he supplicated for her. ${ }^{56}$

On the basis of above traditions, the discourse on Islamic position on medication has been the subject of debate among Muslim jurists since very early times. The majority of scholars (such as Hanafi and Māliki) stated that medical treatment is mubāh (permitted). ${ }^{57}$ The Muslim jurists, namely Shāfi'I jurists such as al-Qadi, and Ibn 'Aqil and Ibn al-Jawzi among the Hanbalis, said that it is mustahāb (recommended). ${ }^{58}$ For the Shafi's, treatment is mustaha $\bar{b}$ when there is no certainty that it will be beneficial. ${ }^{59}$ But when treatment is 
certain to be beneficial (such as putting a dressing on a wound) then it is wäjib (obligatory). ${ }^{60}$

In summary, seeking a treatment or cure is not obligatory unless it will definitely be of benefit. After studying the opinions of fuqahā' (jurists) on the status and scope of medication in Islam, Ali Baar ${ }^{61}$ concludes that there is no doubt that a patient has a choice in having medication or not in some situations. Even withholding medication is better for the patient and his guardians when usefulness of medicine is doubtful, and its harm becomes clear. For instance, when cancer has taken hold of all the body, in such a case medication by surgery or drugs will not be helpful. It will, instead, increase pain and expenses will become burdensome.

In addition, there are also some maxims of Islamic jurisprudence which are applicable to the cases which come under passive euthanasia. Among these principles is al-Umur bimaqāsidiha, which means "Actions shall be judged according to intentions behind them". 62 In a nutshell, intention has a major role in judging action in terms of sin in Islam. For instance, if pain medication is applied to a terminally ill patient to control the pain and coincidentally hastens his death. The judgment, therefore, will be based on the intention of the doctor.

\section{Some Important Issues under Passive Euthanasia}

Taking a comprehensive view of the traditions of Prophet Muhammad and the opinions of jurists based on such traditions, it seems that Islam encourages medication. However, when medication is seemingly useless, refusing, withholding, withdrawing and discontinuing such medication is allowed. Moreover, according to Motlani, ${ }^{63}$ some scholars argue that withdrawing or withholding treatment need not constitute a form of euthanasia. While some scholars consider withdrawing extraordinary treatment as 'passive euthanasia', others consider it a standard or conventionally accepted practice from a medical, spiritual and economic viewpoint. However, scholars such as Warnock, Macdonald and Rachels6 ${ }^{4}$ believe that there is no moral difference between 'active' and 'passive' euthanasia since the intention and outcome may be the same in both cases, while scholars like Craig and Putilo ${ }^{65}$ believe that lack of clear intention may also make it difficult to morally distinguish 'active' euthanasia from 'passive' euthanasia.

On the other hand, Muslim scholars such as Tantawi, Uthaymin and Al-Qaradawi share the view that there is a difference between the two ('active' and 'passive' euthanasia). ${ }^{66}$ For instance, Yusuf al-Qaradawi, while analyzing opinions of Islamic scholars on medication formulates the following position regarding the issue of euthanasia: "This act (active euthanasia) is Islamically forbidden for it encompasses a positive role on the part of the physician to end the life of the patient and hasten his death through lethal injection, electric shock, a sharp weapon or any other way. This is an act of killing and killing is a major sin and thus forbidden in Islam" ${ }^{67} \mathrm{He}$, however, differentiates it from mercy killing as follows: “...But it is different from the controversial 'Mercy Killing' as it does not imply a positive action on the part of the physician..."68

On permissibility of suspension of treatment, al-Qaradawi says: "As for the suspension of medical treatment via preventing the patient from his due medication which is, from a medical perspective, thought to be useless, this is permissible and sometimes it is even recommended. Thus, the physician can do this for the sake of the patient's comfort and the relief of his family. Nothing is wrong in this". ${ }^{6}$ 
While commenting on the importance of medication and its suspension in Islam, Muhammad Salih Al-Munajjid says: ${ }^{70}$

If there is no certainty that treatment will be of benefit and indeed, it is likely to cause suffering to the patient, there is nothing at all wrong with not giving the treatment. The patient should not forget to put his trust in Allah and seek refuge in Him, for the gates of heaven are open to those who call on Allah. He may also seek ruqya treatment by reciting Qur'an such as reading al-Fätihah, al-Falaq and an-Nās over himself. This will benefit him psychologically and physically as well as bringing him reward. Allah is the Healer and there is no healer but He.

Regarding withholding medical treatment from terminally ill patients, Abdul-Aziz bin Abdullah bin Baz and Abdur-Razzaq 'Afif allowed DNR in the following cases: ${ }^{71}$

- If the sick person has been taken to hospital and is dead.

- If the patient's condition is not fit for resuscitation according to the opinion of three trustworthy specialist doctors.

- If the patient's sickness is chronic and untreatable and death is inevitable according to three trustworthy specialist doctors.

- If the patient is incapacitated or is in a persistent vegetative state and chronically ill or in the case of cancer in its advanced stages, or chronic heart and lung disease with repeated stoppages of the heart and lungs and three trustworthy doctors have determined that.

- If there is any indication that the patient has brain injury that cannot be treated, according to reports of three trustworthy specialist doctors.

- If reviving the heart and lungs is of no benefit according to opinions of three trustworthy specialist doctors.

In a consistent manner with the above submission, Ali Goma ${ }^{72}$ allows the removal of life support machines if the patient's recovery is not possible. He, however, does not allow the removal of such support system in ordinary use to enhance respiration. The position of the Council of Islamic Jurisprudence and Organization of the Islamic Conference ${ }^{73}-$ also on the issue of discontinuing life support system from those patients - is: "In the case of a patient whose body has been hooked up to life support, it is permissible to remove it if all his brain function has ceased completely, and a committee of three specialist, experienced doctors have determined that this cessation of function is irreversible, even if the heart and breathing are still working mechanically with the help of a machine". ${ }^{74}$

Moreover, our discussion which is basically founded on the Qur'an and traditions of the Prophet and the Muslim jurists has helped in giving a fair insight on major issues under euthanasia. Although advocates of euthanasia, according to Ebrahim $^{75}$ based their arguments on economic factors, consideration of hospital materials and equipment such as space, bed and therapeutic devices that could be used for other patients; and death with dignity. Ebrahim, ${ }^{76}$ however, is of the opinion that economic factors are of no consideration in Islam about euthanasia as it is the responsibility of the head of the Muslim community to make funds available from the Public Treasury (Baytul-Māl) in meeting the medical expenses of the needy. ${ }^{77}$

Ebrahim $^{78}$ continues by saying that as a Muslim no one can say that a patient who is not suffering from a fatal disease will outlive one who is terminally ill. Therefore, the logic of preference being given to one individual over another on the basis of the quality of life has no place in Islam. More funds should be allocated to increase the hospital equipment and 
human resources. On death with dignity, Ebrahim ${ }^{79}$ with reference to the prophetic tradition posits that the suffering that one undergoes as a result of any disease actually benefits one spiritually and has nothing to do with one's dignity. At the same time, a Muslim should not wish for death because of any calamity befalling him but be advised to use pain control and put his trust (tawakkul) in Allah. The Hadith goes thus: 'Abdullah ibn Mas'ūd reported: I visited the Prophet while he was having high fever. I said, 'You have a high fever. Is it because you will have a double reward?' He said, 'Yes. No Muslim is afflicted with any harm but that Allah will remove his sins for him as the leaves of a tree fall down., 80

\section{Conclusion}

We have tried to explain euthanasia from a Muslim perspective. Its two types; active and passive were analysed. The prohibition of active euthanasia and physician-assisted suicide is based on the prohibition of killing an innocent person on which the two primary sources are explicitly clear. Regarding the second type - passive euthanasia, because of its complexity and lack of preciseness, the issues which could be grouped under it are withholding, withdrawing and refusing medical treatment, DNR and discontinuing life support machines, among others. The Muslim position was once again based on the Muslim primary sources and the resolutions of Muslim jurists.

\section{REFERENCES}

1. RR Motlani, "Islam, Euthanasia and Western Christianity: Drawing on Western Christian thinking to develop an expanded Western Sunni Muslim Perspective on Euthanasia". Unpublished thesis, University of Exeter, 2011:6.

2. Motlani, Islam, Euthanasia and Western Christianity," 6.

3. MM Malik, "Euthanasia: Islamic Perspective" in AH Soliu (ed.) "The Islamic Worldview, Ethics and Civilization: Issues in Contemporary Interdisciplinary Discourse”. Malaysia: International Islamic University Press, 2012:229.

4. Malik, Euthanasia: Islamic Perspective, 240.

5. RI Adebayo, Euthanasia in the Light of Islamic Law and Ethics. NATAIS: Journal of the Nigeria Association of Teachers of Arabic and Islamic Studies. Vol. 11, 2008.1.

6. AQ Audah, Criminal Law of Islam. Delhi: International Islamic Publishers. Vol. 4:6.

7. Motlani, Islam, Euthanasia and Western Christianity," 7.

8. Malik, Euthanasia: Islamic Perspective, 229.

9. Malik, Euthanasia: Islamic Perspective, 231.

10. Malik, Euthanasia: Islamic Perspective, 231.

11. BO Ogunsola, "Euthanasia - Church Reaction to its Practice". Journal of Human Studies; School of Arts and Social Sciences, Osun State College of Education, IlaOrangun, vol. 3, No. 1, 2000:16.

12. Ogunsola, "Euthanasia - Church Reaction to its Practice, 17.

13. Malik, Euthanasia: Islamic Perspective, 240.

14. M Robert and E Stuart, Euthanasia: The Moral Issues. Contemporary Issues in Philosophy. New York: Prometheus Books, 1999:91. 
15. Motlani, Islam, Euthanasia and Western Christianity, 5.

16. American Medical Association Council on Ethical and Judicial Affairs, "Decisions on the End of Life" Journal of the American Medical Association 267 (16), 1992:2230.

17. O Margaret, Voluntary Euthanasia and the Common Law. Oxford: Clarendon Press, 1997:16\&17.

18. Margaret, Voluntary Euthanasia, 39.

19. Malik, Euthanasia: Islamic Perspective, 232.

20. Robert and Stuart, Euthanasia, 98.

21. Ogunsola, Euthanasia - Church Reaction to its Practice, 25.

22. Audah, Criminal Law of Islam, 34.

23. Motlani, Islam, Euthanasia and Western Christianity, 5.

24. Malik, Euthanasia: Islamic Perspective, 232.

25. Adebayo, Euthanasia in the Light, 6.

26. Y Al-Qaradawi, "Islam's Stance on Euthanasia" n.d.http://www.islamonline.net/servlet/ Satellite?

27. Adebayo, Euthanasia in the Light, 2.

28. Robert and Stuart, Euthanasia, 98.

29. Ogunsola, Euthanasia, 25.

30. Malik, Euthanasia: Islamic Perspective, 230.

31. Adebayo, Euthanasia in the Light, 6.

32. Al-Qaradawi, Islam's Stance.

33. Muhammad bin Ali Al-Bar, Ahkam Al-Tadawi. Jeddah: Dar Al-Manar, 1416H:44.

34. Motlani, Islam, Euthanasia and Western Christianity, 6.

35. Motlani, Islam, Euthanasia and Western Christianity, 6.

36. As translated by MY Zayid, The Meaning of the Qur'an. Beirut: Dar al-Choura, 1980

37. A M Ebrahim, "Islamic Perspective Euthanasia (Qatl al-rahma)". JIMA, volume 39, 2007:173.

38. The word 'Allah' literarily means 'God'.

39. Malik, Euthanasia: Islamic Perspective, 230.

40. This implies that suicide attack in any form is not allowed in Islam and no excuse could be given under any circumstances to permit it as human life is the property of Allah and it is therefore forbidden for a human to destroy it.

41. See Yusuf Ali's commentary on the Qur'an 5 verse 32. The Holy Qur'an: Text, Translation and Commentary. New Delhi: Goodword Books Ltd. 2007:251.

42. Ebrahim, Euthanasia (Qatl al-rahma), 173.

43. Malik, Euthanasia: Islamic Perspective, 230.

44. Malik, Euthanasia: Islamic Perspective, 230.

45. Malik, Euthanasia: Islamic Perspective, 230.

46. Malik, Euthanasia: Islamic Perspective, 230.

47. Malik, Euthanasia: Islamic Perspective, 230. 
48. Malik, Euthanasia: Islamic Perspective, 230.

49. Majama' Fiqhul Islami, "Life Supportive System” Majallat Majma Al-Fiqh 2 3:807.

50. The word 'companion' (Sahabah in Arabic) refers to the disciple, scribe and family of Prophet Muhammad. A companion, therefore, is someone who met the Prophet, believed in him and died as a Muslim.

51. IMANA Ethics Committee, "Islamic Medical Ethics: The Imana Perspective", Journal of Islamic Medical Association, 37 (July 2005), 33-43.

52. Al-Bukhari, Sahihul Bukhari, 1, 1.

53. Ebrahim, Euthanasia (Qatl al-rahma), 173.

54. Ebrahim, Euthanasia (Qatl al-rahma, 173.

55. Malik, Euthanasia: Islamic Perspective, 235.

56. Al-Qaradawi, Islam's Stance.

57. Robert and Stuart, Euthanasia, 100.

58. Al-Qaradawi, Islam's Stance.

59. Al-Qaradawi, Islam's Stance.

60. Adebayo, Euthanasia in the Light, 7.

61. Adebayo, Euthanasia in the Light, 10.

62. Malik, Euthanasia: Islamic Perspective, 245.

63. Motlani, Islam, Euthanasia and Western Christianity, 6.

64. Motlani, Islam, Euthanasia and Western Christianity, 6.

65. Motlani, Islam, Euthanasia and Western Christianity, 6.

66. Motlani, Islam, Euthanasia and Western Christianity, 6.

67. Malik, Euthanasia: Islamic Perspective, 245.

68. Malik, Euthanasia: Islamic Perspective, 245.

69. Muhammad bin Ali Al-Bar, Ahkam.

70. Majama ' Fiqhul Islami, Life Supportive.

71. www.islamicity.com - A Sign on the Road to Makkah (visited on 5th September, 2013.

72. Majama‘ Fiqhul Islami, Life Supportive.

73. www.islamicity.com-A Sign on the Road.

74. Malik, Euthanasia: Islamic Perspective, 246.

75. Malik, Euthanasia: Islamic Perspective, 230.

76. Ebrahim, Euthanasia (Qatl al-rahma), 176.

77. Ebrahim, Euthanasia (Qatl al-rahma), 176.

78. Ebrahim, Euthanasia (Qatl al-rahma), 176.

79. Ebrahim, Euthanasia (Qatl al-rahma), 176.

80. Ebrahim, Euthanasia (Qatl al-rahma), 176. 